\title{
Twenty-four-hour profiles of prolactin and testosterone in ram lambs exposed to skeleton photoperiods consisting of various light pulses
}

\author{
B. D. Schanbacher, W. Wu, J. A. Nienaber and G. L. Hahn \\ Roman L. Hruska U.S. Meat Animal Research Center, Agricultural Research Service, \\ U.S. Department of Agriculture, Clay Center, Nebraska 68933, U.S.A.
}

\begin{abstract}
Summary. Individual groups of 6 ram lambs were housed within a controlled environment and exposed to one of 6 photoperiod schedules. Groups I and II received 8 (short day) or 16 (long day) h of continuous light, respectively; Groups III, IV and V were exposed to asymmetrical skeleton photoperiods consisting of a main light period of $7 \mathrm{~h}$ followed $9 \mathrm{~h}$ later by a light pulse of $1 \mathrm{~h}, 15 \mathrm{~min}$ or $1 \mathrm{~min}$ duration, respectively, and Group VI was exposed to a symmetrical skeleton photoperiod consisting of two 1-h light pulses positioned $16 \mathrm{~h}$ apart. After 4 weeks of treatment serum concentrations of prolactin and testosterone were measured over $24 \mathrm{~h}$. Long-day responses characteristic of the 16L:8D photoperiod (i.e. elevated prolactin and reduced testosterone) were obtained in each of the asymmetric light-pulse treatment groups, but whereas prolactin was elevated over the full $24 \mathrm{~h}$ in lambs exposed to $16 \mathrm{~L}: 8 \mathrm{D}$, two prominent nocturnal prolactin releases were largely responsible for the high 24 -h mean prolactin values in Groups III, IV and V. Reduced serum testosterone in these same groups could not be attributed to a diurnal pattern of secretion but was associated with an overall decrease in testosterone pulse frequency. Prolactin and testosterone levels in Group IV were intermediate between those observed in lambs exposed to 8 or $16 \mathrm{~h}$ of light. In summary, light pulses of short duration $(1 \mathrm{~min}$ ) positioned at $17 \mathrm{~h}$ after dawn can produce endocrine changes in lambs similar to those observed in lambs exposed to $16 \mathrm{~h}$ of continuous light.
\end{abstract}

\section{Introduction}

Domestic sheep, like their primitive ancestors, are seasonal breeders whose breeding activity is restricted to the short days of autumn. The ewe exhibits oestrus during the autumn and gives birth during the spring. The ram also contributes to seasonal propagation of the species by displaying sexual cycles compatible with fall breeding (Lincoln \& Short, 1980; Haynes \& Schanbacher, 1983). Hypertrophy and regression of the testes, waxing and waning of circulating androgen and changes in sexual aggression arise from an endogenous rhythm (Howles, Webster \& Haynes, 1980) which is normally entrained to an annual cycle by seasonal constraints in the environment. Entrainment to shorter cycles can be accomplished experimentally by exposure to environments in which contrasting daylengths are imposed (Pelletier \& Ortavant, 1975; Lincoln \& Davidson, 1977; Sanford, Beaton, Howland \& Palmer, 1978; D’Occhio, Schanbacher \& Kinder, 1984).

Increased awareness of the importance of daylength in the control of reproductive function in sheep not only provides us with insight into the basic endocrine mechanisms controlling reproduction (Lincoln, 1978) but also provides the sheep producer with information which can be used to enhance reproductive efficiency of the farm flock (Schanbacher, 1979) and to improve growth, performance and profitability of lamb production (Schanbacher \& Crouse, 1980).

Skeleton photoperiods consisting of light pulses (flashes) have been imposed to determine 
which particular phase of the circadian cycle is important for photoinduction. Utilization of an asymmetrical skeleton (i.e. a main light period of $7 \mathrm{~h}$ followed by a $1-\mathrm{h}$ light pulse positioned at different points throughout the night) permitted Ravault \& Ortavant (1977) to define a photoinducible phase for prolactin secretion at $17 \mathrm{~h}$ after dawn. The ability of a 1-h light pulse at hour 17 to enhance prolactin secretion in the ram was subsequently confirmed by Schanbacher \& Crouse (1981) and Schanbacher (1982). The importance of the duration of this light flash, however, and the ability of symmetrical skeletons (i.e. two light pulses of equal duration) to affect prolactin in sheep have been examined in the present study. Testosterone profiles were included to provide an indicator of testicular activity in response to photoperiod treatment.

\section{Materials and Methods}

General management and blood sampling

Suffolk-sired crossbred ram lambs weighing approximately $45 \mathrm{~kg}$ and about 28 weeks old were removed from a naturally lighted group feeding pen, stratified by age and weight and assigned to one of 6 treatment groups $(\mathrm{N}=6 /$ group). The lambs were paired within treatment for feeding purposes and placed by treatment group within separate environmentally controlled chambers in December. All chambers were maintained at $18^{\circ} \mathrm{C}$ with relative humidity near $45 \%$ and provided one of the 6 photoperiod treatments. Incandescent light at 200 lux intensity was provided such that lambs in Groups I and II received 8 and $16 \mathrm{~h}$ of continuous light respectively. The asymmetrical skeleton photoperiods imposed on lambs in Groups III, IV and V consisted of a main light period of $7 \mathrm{~h}$ followed $9 \mathrm{~h}$ later by a light pulse of either $1 \mathrm{~h}$ (Group III), $15 \mathrm{~min}$ (Group IV), or $1 \mathrm{~min}$ (Group V), respectively. Group VI lambs were exposed to a symmetrical skeleton photoperiod consisting of a $\mathrm{l}$-h light period each morning followed $15 \mathrm{~h}$ later by a second 1 -h light period. Dawn was the same for each treatment group (i.e. $08: 00 \mathrm{~h}$ ). Feeders were filled daily shortly after $08: 00 \mathrm{~h}$ for ad-libitum feeding of a pelleted ration consisting of ground shelled corn, alfalfa hay, soybean and supplement. This diet was analysed to contain $90 \%$ dry matter, $17 \%$ crude protein and $79 \%$ total digestible nutrients. Water was provided continuously.

After exposure to the treatment photoperiod for 4 weeks, the lambs were equipped with an indwelling jugular cannula and placed into individual pens to simplify the blood sampling procedure which was to follow. The next day, 3-ml blood samples were collected from each animal at hourly intervals starting at $08: 00 \mathrm{~h}$. Sampling for $24 \mathrm{~h}$ was accomplished from outside each pen to minimize disturbance of each lamb's light/dark cycle and associated diurnal behaviour. The blood was allowed to clot and the serum subsequently collected and frozen.

\section{Hormone radioimmunoassay}

Serum prolactin concentrations were determined in duplicate by double-antibody radioimmunoassay as previously described (Schanbacher, 1980; Schanbacher \& Crouse, 1981). NIH-PS8 was used as the reference standard and assay sensitivity was $1 \mathrm{ng} / \mathrm{ml}$. Animals from each treatment group were included in each of 6 assays in which the intra-assay coefficient of variation was $<12 \%$. The inter-assay coefficient of variation for three serum pools was $6.4 \%$.

Testosterone concentrations were also determined by double-antibody radioimmunoassay (Schanbacher \& D'Occhio, 1982). All samples were assayed in duplicate within 1 of 6 assays. Sensitivity of testosterone radioimmunoassay by this procedure was $0.1 \mathrm{ng} / \mathrm{ml}$. Intra- and interassay coefficients of variation were 8.5 and $7 \cdot 1 \%$ respectively.

\section{Statistical analyses}

The 24-h means for prolactin and testosterone concentrations and numbers of testosterone pulses per $24 \mathrm{~h}$ were determined for each animal (Schanbacher \& Ford, 1976) and the effects of 
treatment assessed by one-way analyses of variance (Dixon \& Massey, 1969). Mean separation was accomplished by Duncan's new multiple range test. In addition, light/dark (L/D) ratios were calculated by dividing the mean serum hormone concentrations during the initial light hours after dawn by the mean of the remaining 24-h period for each animal to test whether a diurnal rhythm existed for the secretion of prolactin or testosterone. This was accomplished by testing the hypothesis that these ratios differed significantly from unity using a modified $t$ test (Dixon \& Massey, 1969).

\section{Results}

The 24-h secretory profiles of prolactin and testosterone for each treatment group are given in Textfig. 1 and the effects of these treatments on mean hormone concentrations are summarized in Table 1. Daylength had inverse effects on these hormones such that lambs exposed to a $16-\mathrm{h}$ day $(16 \mathrm{~L}: 8 \mathrm{D}$,
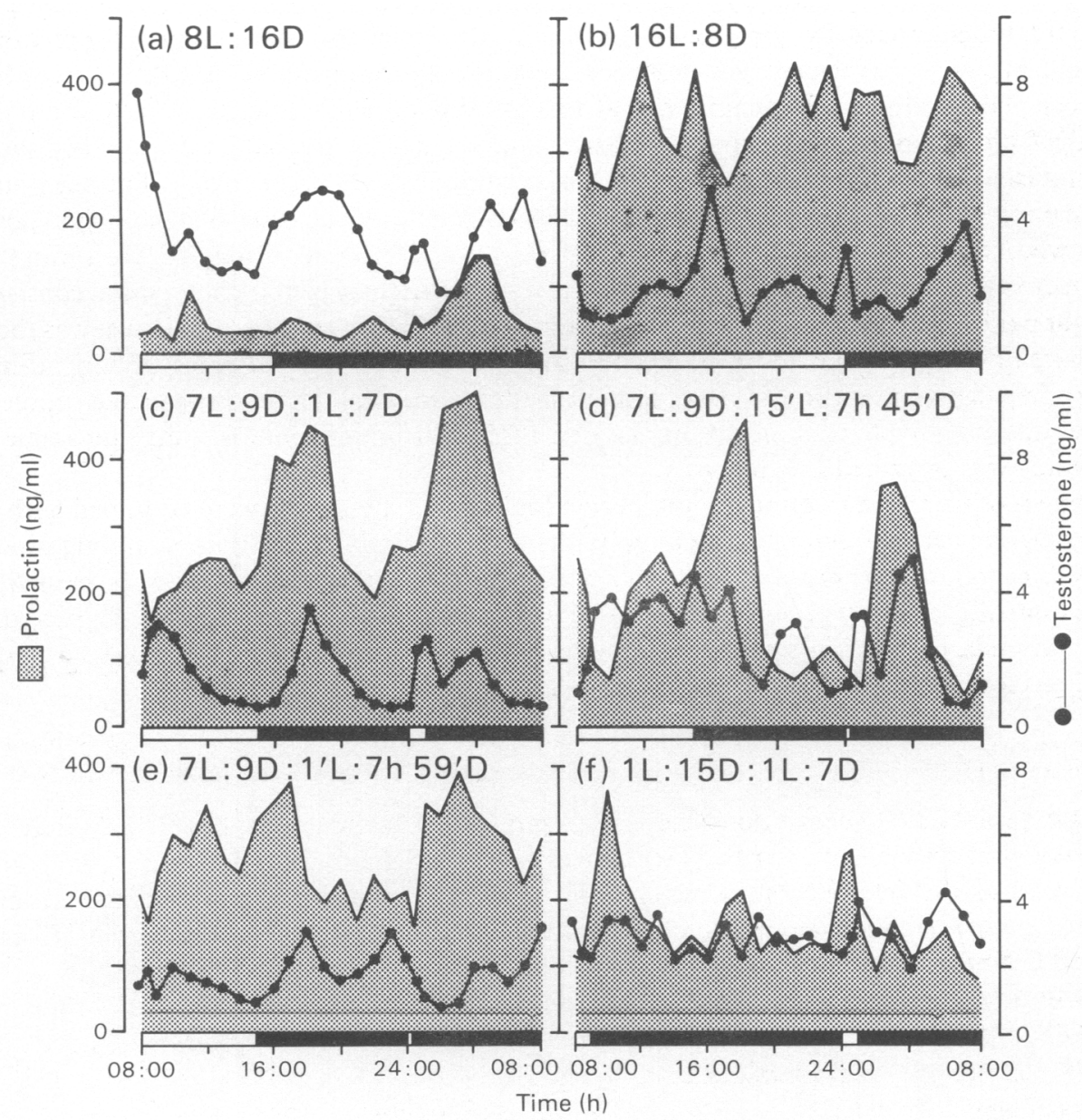

Text-fig. 1. Mean profiles of prolactin and testosterone for lambs exposed to (a) a short 8-h day (Group I); (b) a long 16-h day (Group II); an asymmetrical skeleton photoperiod after 7L :9D, (c) 1 h, Group III, (d) 15 min, Group IV, (e) 1 min, Group V; or (f) a 1-h symmetrical skeleton photoperiod (Group VI). The photoperiods are schematically illustrated at the bottom of each figure by open and closed bars. 
Table 1. Prolactin and testosterone responses of ram lambs exposed to six different photoperiods

\begin{tabular}{|c|c|c|c|c|c|c|}
\hline \multirow[b]{2}{*}{ Photoperiod treatment } & \multirow[b]{2}{*}{$\begin{array}{l}\text { No. of } \\
\text { lambs }\end{array}$} & \multicolumn{2}{|c|}{ Prolactin } & \multicolumn{3}{|c|}{ Testosterone } \\
\hline & & $\begin{array}{l}\text { 24-h mean } \\
(\mathrm{ng} / \mathrm{ml})\end{array}$ & $\begin{array}{l}\text { Ratio } \\
(\mathrm{L} / \mathrm{D}) \dagger\end{array}$ & $\begin{array}{l}\text { 24-h mean } \\
(\mathrm{ng} / \mathrm{ml})\end{array}$ & $\begin{array}{c}\text { No. of } \\
\text { pulses } / 24 \mathrm{~h}\end{array}$ & $\begin{array}{l}\text { Ratio } \\
(\mathrm{L} / \mathrm{D}) \dagger\end{array}$ \\
\hline \multicolumn{7}{|l|}{ Controls } \\
\hline $8 \mathrm{~L}: 16 \mathrm{D}$ & 6 & $55^{\mathrm{b}}$ & $0.71^{*}$ & $3 \cdot 7^{b}$ & $7 \cdot 7^{\mathrm{b}}$ & $1 \cdot 14$ \\
\hline $16 \mathrm{~L}: 8 \mathrm{D}$ & 6 & $348^{\mathrm{d}}$ & 0.92 & $2 \cdot 0^{\mathrm{d}}$ & $2 \cdot 2^{\mathrm{c}}$ & 1.04 \\
\hline \multicolumn{7}{|l|}{ Asymmetrical skeletons } \\
\hline $\begin{array}{c}7 \mathrm{~L}: 9 \mathrm{D}: \mathrm{IL}: 7 \mathrm{D} \\
(1-\mathrm{h} \text { pulse })\end{array}$ & 6 & $296^{\mathrm{d}}$ & $0 \cdot 65^{* *}$ & $1 \cdot 6^{\mathrm{d}}$ & $1.8^{\mathrm{c}}$ & $1 \cdot 13$ \\
\hline $\begin{array}{c}7 \mathrm{~L}: 9 \mathrm{D}: 15^{\prime} \mathrm{L}: 7 \mathrm{~h} 45^{\prime} \mathrm{D} \\
(15-\text { min pulse })\end{array}$ & 6 & $229^{\mathrm{cd}}$ & 1.05 & $2 \cdot 6^{\mathrm{c}}$ & $2 \cdot 7^{\mathrm{c}}$ & $1 \cdot 26$ \\
\hline $\begin{array}{l}7 \mathrm{~L}: 9 \mathrm{D}: \mathrm{I}^{\prime} \mathrm{L}: 7 \mathrm{~h} 59^{\prime} \mathrm{D} \\
(1-\text { min pulse })\end{array}$ & 6 & $267^{\mathrm{d}}$ & 0.96 & $1 \cdot 8^{\mathrm{d}}$ & $2 \cdot 2^{\mathrm{c}}$ & 0.74 \\
\hline $\begin{array}{l}\text { Symmetrical skeleton } \\
1 \mathrm{~L}: 15 \mathrm{D}: 1 \mathrm{~L}: 7 \mathrm{D}\end{array}$ & 6 & $148^{\mathrm{c}}$ & 0.87 & $2 \cdot 9^{c}$ & $3 \cdot 4^{\mathrm{c}}$ & 0.88 \\
\hline
\end{tabular}

$\dagger$ Ratios were calculated from mean hormone concentrations during the initial light hours after dawn (i.e. $8 \mathrm{~h}$ for the $8 \mathrm{~L}: 16 \mathrm{D}$ controls; $16 \mathrm{~h}$ for the $16 \mathrm{~L}: 8 \mathrm{D}$ controls; $7 \mathrm{~h}$ for the asymmetrical skeletons; and $1 \mathrm{~h}$ for the symmetrical skeleton) divided by the mean of the remaining 24 -h period. Values marked by asterisks differ from unity, ${ }^{*} P<0.05$; ${ }^{* *} P<0.01$.

bed Twenty-four hour means and no. of pulses were calculated from the 24-h profiles. Values in the same column with different superscripts differ significantly $(P<0.01)$.

Group II) had increased $(P<0.01)$ prolactin and decreased $(P<0.01)$ testosterone concentrations when compared to lambs exposed to only an 8 -h day $(8 \mathrm{~L}: 16 \mathrm{D}$, Group I). Each of the asymmetrical skeleton photoperiods consisting of a light pulse (flash) during the 17 th hour after dawn resulted in mean prolactin levels in Groups III, IV and V comparable to those observed for lambs exposed to a 16-h continuous day (Group II). Testosterone was reduced significantly in lambs exposed to the short-day asymmetrical skeletons (Groups III-V) when compared to short days consisting of $8 \mathrm{~h}$ of continuous light (Group I). The symmetrical skeleton photoperiod consisting of two 1-h light pulses positioned $16 \mathrm{~h}$ apart (relative to dawn, Group VI) resulted in significant but intermediate changes in prolactin values. The elevated prolactin concentrations observed in this group suggested that the lambs perceived this skeleton photoperiod as a long day. However, the intermediate rise in prolactin (Table 1) and absence of a prolactin surge after the light flash at 24:00 h (Text-fig. If) suggest that these lambs may be interpreting this skeleton photoperiod as a short day by assigning dawn to the second 1-h light pulse situated at 24:00 h. The 24-h mean testosterone concentration in this group was also intermediate between that of Groups I and II (Table 1). The reductions in 24-h mean testosterone concentrations observed in lambs in Groups II, III, IV, V and VI were accompanied by a significant reduction in testosterone pulse frequency.

Considerable fluctuations were observed for concentrations of prolactin and testosterone over the 24-h blood sampling period, but those for prolactin were more synchronous and prolonged. Prolactin, for example, was substantially elevated in 4 of 6 lambs in Group I during the early morning hours (near 04:00 h). Synchrony was particularly conspicuous in the 12 lambs in Groups III and IV; 2 nocturnal rises in prolactin were observed; one commencing at dusk and the other immediately after the light pulse at $24: 00 \mathrm{~h}$ (Text-figs $1 \mathrm{c} \& 1 \mathrm{~d}$ ). A similar bimodal fluctuation in prolactin was observed in 5 of 6 lambs in Group $V$ but the amplitudes of these changes were less dramatic. No comparable synchrony was observed for serum testosterone in the lambs of this study.

The nocturnal rise in serum prolactin of lambs in Groups I and III was reflected in the decreased $\mathrm{L} / \mathrm{D}$ ratio of prolactin for these groups. Although the prolactin secretory pattern differed for the other four treated groups, the L/D ratios were not significantly different from unity suggesting that 24 -h mean prolactin levels can be estimated by limiting blood sampling to the initial day- 
light hours. The $\mathrm{L} / \mathrm{D}$ ratios for testosterone indicate that a diurnal rhythm does not exist for its secretion.

\section{Discussion}

The results clearly indicate the position of a light sensitive phase during the light-dark cycle in sheep and further show that very short pulses or flashes of light received during this period are sufficient to entrain endogenous rhythms which participate in the regulation of prolactin and testosterone secretion. Although daily light pulses of short duration are known to affect growth and maintenance of the testis in rodents (Ellis \& Follett, 1983) and birds (Follett \& Milette, 1982), the limited number of investigations in sheep have been directed towards the regulation of prolactin secretion rather than the control of gonadal function. Results from the present study with asymmetrical skeleton photoperiods provide additional data in support of a defined photosensitive period during the 17th hour after dawn for prolactin secretion in sheep (Ravault \& Ortavant, 1977; Schanbacher \& Crouse, 1981). Although mean serum prolactin levels were elevated when there were asymmetrical skeleton photoperiods, this effect was achieved by a pronounced biphasic pattern of prolactin secretion. Our findings also demonstrate the potency by which a very short pulse of light between the 16th and 17th hour after dawn can mimic a long day and inhibit testosterone secretion by the testis.

Interpretation of hormonal data from the asymmetrical skeleton treatments in the present study appears straightforward. Nonetheless, to counter the argument that the initial long light period is actually responsible for any given biological response, an experiment using symmetrical light pulses was conducted (Group VI). The one symmetrical skeleton photoperiod imposed in this study gave prolactin and testosterone responses that were intermediate between those for long and short days. When similar experiments have been carried out with hamsters using as little as two daily 1-sec light pulses, testicular growth was virtually maximal (i.e. identical to that observed when animals were placed on stimulatory long days) (Ellis \& Follett, 1983). In view of these findings, our study in sheep with symmetrical light pulses should be re-examined.

Initially, one might suspect that photoinduced prolactin release might enhance testosterone secretion as previously suggested by Bartke, Smith, Michael, Perin \& Dalterio (1977); however, a positive effect of prolactin on testosterone secretion appears to be limited to rodents and possibly other long-day breeders, since investigators have reported only a negative relationship between these two hormones in sheep. Testosterone levels were unaffected when prolactin secretion was blocked in this species by bromocriptine (Ravault, Courot, Garnier, Pelletier \& Terqui, 1977), thereby providing additional evidence that testosterone secretion in short-day breeders is not influenced by prolactin. The small positive effect of testosterone on prolactin which has been reported previously for the ram (Schanbacher, 1980) does not seem particularly relevant to this study in view of the relatively large effect of photoperiod on prolactin and small effect on testosterone.

Discrimination between long and short days is no doubt paramount to the survival of sheep and identification of the light-sensitive phase will probably prove to be important in defining the mechanism of photoperiodicity. Presumably the regular periodicity of the light sensitive phase depends on the activity of an intrinsic oscillator or biological clock (Takahashi \& Zatz, 1982). Based on research work with rodents, the mammalian clock is believed to reside within the suprachiasmatic nucleus of the hypothalamus (Rusak \& Zucker, 1979).

The pineal is believed to be the gland through which light is transformed into a chemical signal (Barrell \& Lapwood, 1979) and melatonin the messenger of this activity (Reiter, 1980). There is some evidence that melatonin is the chemical messenger for photoperiod measurement in ewes (Kennaway, Gilmore \& Seamark, 1982; Nett \& Niswender, 1982). Regardless of the central mechanisms whereby skeleton photoperiods alter prolactin and testosterone secretion, it is clear that a light flash at the 17th hour after dawn results in levels of these hormones which are remarkably 
similar to levels observed in rams exposed to $16 \mathrm{~h}$ of continuous light. The pattern of prolactin secretion differs between young rams exposed to a light flash in the 17 th hour and those exposed to long days in that nocturnal surges of prolactin contributed to the elevated $24-\mathrm{h}$ means. Both nocturnal surges, one at dusk and the other shortly after the light fiash, have been reported previously (Ravault \& Ortavant, 1977; Ravault, Daveau \& Ortavant, 1981). These investigators also reported prolactin surges at dusk in rams exposed to regular long and short days. The absence of notable surges at dusk in the present study suggests that the profiles of prolactin secretion in 16-h long days and in 8-h short days should be reassessed. Undoubtedly, different mechanisms are involved with asymmetrical skeleton photoperiods to achieve 'long-day effects' with respect to prolactin secretion and perhaps other hormones. Ravault et al. (1981) confirmed and extended their earlier observations to suggest that the photosensitive phase for prolactin release at hour 17 after dawn is actually based on a dusk signal. This finding is particularly relevant to those scientists and producers wishing to position properly light flashes in sheep whose endogenous rhythms are adjusting to changes in natural daylength (i.e. dusk). In contrast to a dusk signal for identifying the photosensitive phase for prolactin secretion, gonadotrophin secretion (and thus testosterone) appears to be synchronized by a dawn signal (Ortavant et al., 1982). The importance of a dawn signal for activation of the pituitary-testicular endocrine axis was provided by Pelletier et al. (1981) who monitored the effects of light flashes on testicular diameter and reported a stimulatory effect of the 17 th hour light flash on LH, FSH and testosterone secretion. In contrast, our results show an inhibitory effect of this treatment on serum testosterone concentrations (Group III). The reasons for this discrepancy are unclear (Schanbacher \& Crouse, 1981), but may involve a time component, since the stimulatory effects reported by Pelletier et al. (1981) were most apparent after 16 weeks of exposure to the light flash.

The practical value of the information contained in this study pertains to the finding that light pulses can be used to alter the endocrine systems that affect growth and reproduction. Light pulses can be imposed on groups of animals to increase prolactin and enhance growth rates of ram lambs (Schanbacher \& Crouse, 1980, 1981) and we presume, based on the differential effects of long and short days on growth of ewe lambs (Schanbacher, Hahn \& Nienaber, 1982), that pulses of light will be found to be beneficial to production efficiency of intensively managed lambs of both sexes. Similarly, very short light pulses might be imposed during the early winter months to synchronize the animals entering the subsequent anoestrous period. In turn, ewes may be stimulated to begin breeding in advance of the normal breeding season once the supplementary light is no longer provided.

Ortavant et al. (1982) have reported a diurnal rhythm of testosterone secretion in the ram; however, data from our laboratory (Schanbacher \& Ford, 1976; D’Occhio et al., 1982, 1984) fail to support such a conclusion. It therefore seems reasonable to conclude that daytime blood sampling is adequate to describe the testosterone response of ram lambs exposed to contrasting photoperiod environments. Caution should be exercised, however, when interpreting prolactin data because of the presence of nocturnal surges of this hormone.

We thank Tom Bishop and Cindy Rainbolt for technical assistance, Deborah Brown for secretarial assistance, and the Nebraska Agricultural Experiment Station, University of Nebraska, Lincoln, for its co-operation.

\section{References}

Barrell, G.K. \& Lapwood, K.R. (1979) Effects of pinealectomy on the secretion of luteinizing hormone, testosterone and prolactin in rams exposed to various lighting regimes. J. Endocr. 80, 397-405.

Bartke, A., Smith, M.S., Michael, S.D., Perin, F.G. \& Dalterio, S. (1977) Effects of experimentally-induced chronic hyperprolactinemia on testosterone and gonadotropin levels in male rats and mice. Endocrino$\log y$ 100, 182-186.

Dixon, W.J. \& Massey, F.J., Jr (1969) Introduction to Statistical Analysis, 3rd edn, pp. 98-99; 156-162. McGraw-Hill, New York. 
D'Occhio, M.J., Schanbacher, B.D. \& Kinder, J.E. (1982) Relationship between serum testosterone concentration and patterns of luteinizing hormone secretion in male sheep. Endocrinology 110, 1547-1554.

D'Occhio, M.J., Schanbacher, B.D. \& Kinder, J.E. (1984) Profiles of luteinizing hormone, follicle stimulating hormone, testosterone and prolactin in rams of diverse breeds: effects of contrasting short (8L:16D) and long (16L:8D) photoperiods. Biol. Reprod. 30, 1141-1157.

Ellis, D.H. \& Follett, B.K. (1983) Gonadotropin secretion and testicular function in golden hamsters exposed to skeleton photoperiods with ultrashort light pulses. Biol. Reprod. 29, 805-818.

Follett, B.K. \& Milette, J.J. (1982) Photoperiodism in quail: testicular growth and maintenance under skeleton photoperiods. J. Endocr. 93, 83-90.

Haynes, N.B. \& Schanbacher, B.D. (1983) The control of reproductive activity in the ram. In Sheep Production, pp. 431-451. Ed. W. Haresign. Butterworth, London.

Howles, C.M., Webster, G.M. \& Haynes, N.B. (1980) The effect of rearing under a long or short photoperiod on testis growth, plasma testosterone and prolactin concentrations and the development of sexual behaviour in rams. J. Reprod. Fert. 60, 437-447.

Kennaway, D.J., Gilmore, T.A. \& Seamark, R.F. (1982) The effect of melatonin feeding on serum prolactin and gonadotropin levels and the onset of seasonal estrous cyclicity in sheep. Endocrinology 110, 17661772.

Lincoln, G.A. (1978) Hypothalamic control of the testes in the ram. Int. J. Androl. 1, 331-341.

Lincoln, G.A. \& Davidson, W. (1977) The relationship between sexual and aggressive behaviour and pituitary and testicular activity during the seasonal sexual cycle of rams, and the influence of photoperiod. $J$. Reprod. Fert. 49, 267-276.

Lincoln, G.A. \& Short, R.V. (1980) Seasonal breeding: Nature's contraceptive. Recent Prog. Horm. Res. 36, 1-52.

Nett, T.M. \& Niswender, G.D. (1982) Influence of exogenous melatonin on seasonality of reproduction in sheep. Theriogenology 17, 645-653.

Ortavant, R., Daveau, A., Garnier, D.H., Pelletier, J., de Reviers, M.M. \& Terqui, M. (1982) Diurnal variation in release of $\mathrm{LH}$ and testosterone in the ram. $J$. Reprod. Fert. 64, 347-353.

Pelletier, J. \& Ortavant, R. (1975) Photoperiodic control of $L H$ release in the ram. Light-androgen interaction. Acta endocr., Copenh. 78, 442-450.

Pelletier, J., Blanc, M., Daveau, A., Garnier, D.H., Ortavant, R., de Reviers, M.M. \& Terqui, M. (1981) Mechanism of light action in the ram: a photosensitive phase for $\mathrm{LH}, \mathrm{FSH}$, testosterone and testis weight? In Photoperiodism and Reproduction, pp. 117134. Eds R. Ortavant, J. Pelletier \& J. P. Ravault. I.N.R.A. Publications, Versailles.
Ravault, J.P. \& Ortavant, R. (1977) Light control of prolactin secretion in sheep. Evidence for a photoinducible phase during a diurnal rhythm. Annls Biol. anim. Biochim. Biophys. 17, 459-473.

Ravault, J.P., Courot, M., Garnier, D., Pelletier, J. \& Terqui, M. (1977) Effect of 2-bromo- $\alpha$-ergo-cryptine (CB 154) on plasma prolactin, $\mathrm{LH}$ and testosterone levels, accessory reproductive glands and spermatogenesis in lambs during puberty. Biol. Reprod. 17, 192-197.

Ravault, J.P., Daveau, A. \& Ortavant, R. (1981) Evidence for a photosensitive phase for prolactin secretion in relation to the dusk in rams. In Photoperiodism and Reproduction, pp. 135-146. Eds R. Ortavant, J. Pelletier \& J. P. Ravault. I.N.R.A. Publications, Versailles.

Reiter, R.J. (1980) Photoperiod: its importance as an impeller of pineal and seasonal reproductive rhythms. Int. J. Biometeor. 24, 57-63.

Rusak, B. \& Zucker, I. (1979) Neural regulation of circadian rhythms. Physiol. Rev. 59, 449-526.

Sanford, L.M., Beaton, D.B., Howland, B.E. \& Palmer, W.M. (1978) Photoperiod-induced changes in LH, FSH, prolactin and testosterone secretion in the ram. Can. J. Anim. Sci. 58, 123-128.

Schanbacher, B.D. (1979) Increased lamb production with rams exposed to short daylengths during the non-breeding season. J. Anim. Sci. 49, 927-932.

Schanbacher, B.D. (1980) Influence of testicular steroids on thyrotropin releasing hormone-induced prolactin release in mature rams. J. Androl. 1, 121-126.

Schanbacher, B.D. (1982) Responses of ram lambs to active immunization against testosterone and luteinizing hormone-releasing hormone. Am. J. Physiol. 242, E201-E205.

Schanbacher, B.D. \& Crouse, J.D. (1980) Growth and performance of growing finishing lambs exposed to long or short photoperiods. J. Anim. Sci. 51, 943-948.

Schanbacher, B.D. \& Crouse, J. D. (1981) Photoperiodic regulation of growth: a photosensitive phase during light-dark cycle. Am. J. Physiol. 241, E1-E5.

Schanbacher, B.D. \& D'Occhio, M.J. (1982) Validation of a direct radioimmunoassay for testosterone in unextracted serum from five species: application to study of the hypothalamic-pituitary-gonadal axis in males. J. Androl. 3, 45-51.

Schanbacher, B.D. \& Ford, J.J. (1976) Seasonal profiles of plasma luteinizing hormone, testosterone and estradiol in the ram. Endocrinology 99, 752-757.

Schanbacher, B.D., Hahn, G.L. \& Nienaber, J.A. (1982) Effects of contrasting photoperiods and temperatures on performance traits of confinement-reared ewe lambs. J. Anim. Sci. 55, 620-626.

Takahashi, J.S. \& Zatz, M. (1982) Regulation of circadian rhythmicity. Science, N.Y. 217, 1104-1111.

Received 1 March 1984 